\title{
Scoping Report: Advanced Technologies for Multi-Load Washers in Hospitality and Healthcare
}

$\begin{array}{ll}\text { GB Parker } & \text { WJ Goetzler } \\ \text { BK Boyd } & \text { KJ Foley } \\ \text { JM Petersen } & \text { TA Sutherland }\end{array}$

March 2013

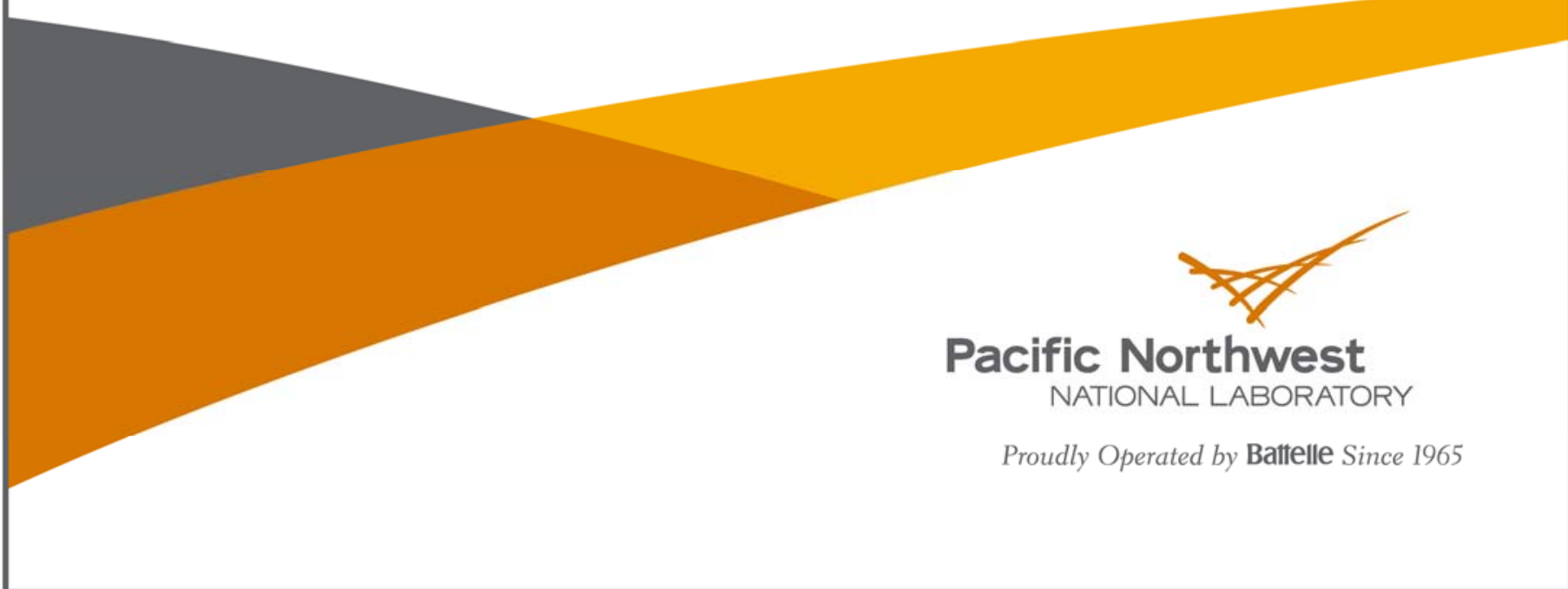




\title{
DISCLAIMER
}

This report was prepared as an account of work sponsored by an agency of the United States Government. Neither the United States Government nor any agency thereof, nor Battelle Memorial Institute, nor any of their employees, makes any warranty, express or implied, or assumes any legal liability or responsibility for the accuracy, completeness, or usefulness of any information, apparatus, product, or process disclosed, or represents that its use would not infringe privately owned rights. Reference herein to any specific commercial product, process, or service by trade name, trademark, manufacturer, or otherwise does not necessarily constitute or imply its endorsement, recommendation, or favoring by the United States Government or any agency thereof, or Battelle Memorial Institute. The views and opinions of authors expressed herein do not necessarily state or reflect those of the United States Government or any agency thereof.

\author{
PACIFIC NORTHWEST NATIONAL LABORATORY \\ operated by \\ BATTELLE \\ for the \\ UNITED STATES DEPARTMENT OF ENERGY \\ under Contract DE-AC05-76RL01830
}

Printed in the United States of America
Available to DOE and DOE contractors from the Office of Scientific and Technical Information, P.O. Box 62, Oak Ridge, TN 37831-0062; ph: (865) 576-8401 fax: $(865) 576-5728$
email: reports@adonis.osti.gov
Available to the public from the National Technical Information Service 5301 Shawnee Rd., Alexandria, VA 22312 ph: (800) 553-NTIS (6847) email: orders $a$ ntis.gov $<$ http://www.ntis.gov/about/form.aspx> Online ordering: http://www.ntis.gov




\title{
Scoping Report: Advanced Technologies for Multi-Load Washers in Hospitality and Healthcare
}

\author{
GB Parker \\ WJ Goetzler ${ }^{1}$ \\ BK Boyd \\ KJ Foley ${ }^{1}$ \\ JM Petersen \\ TA Sutherland ${ }^{1}$
}

March 2013

Prepared for

Commercial Buildings

Buildings Technologies Office

Pacific Northwest National Laboratory

Richland, Washington 99352

\footnotetext{
${ }^{1}$ Navigant Consulting, Inc., Burlington, Massachusetts
} 



\section{Summary}

This scoping report provides a roadmap for the identification, selection, and metering approach for the demonstration of retrofit high performance laundry system technologies in the hospitality and healthcare sectors. The desired outcome of this project is to increase the penetration of efficient laundry technologies in the hospitality and healthcare industries. This report identifies the efficient retrofit technologies to be demonstrated, the potential energy and water savings from a retrofit of those technologies, and the commercial providers of those technologies. An approach is recommended for the selection of candidate sites for technology demonstration and supporting data is included to assist in site selection. Further, approaches to metering and data collection are provided for determining the performance and energy and water savings of the technologies. In addition, recommendations are made regarding how to ascertain user and customer satisfaction. 



\section{Acronyms and Abbreviations}

$\begin{array}{ll}\text { BBA } & \text { Better Buildings Alliance } \\ \text { DOE } & \text { U.S. Department of Energy } \\ \text { NCI } & \text { Navigant Consulting, Inc. } \\ \text { OPL } & \text { On-premise laundry } \\ \text { PNNL } & \text { Pacific Northwest National Laboratory } \\ \text { SHG } & \text { Saunders Hotel Group }\end{array}$





\section{Contents}

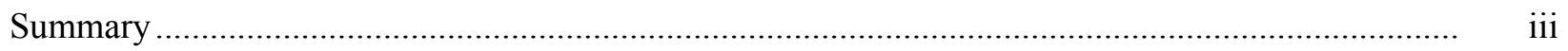

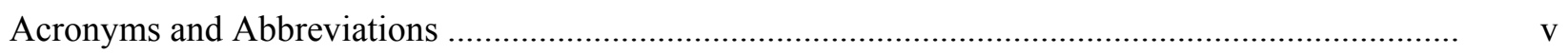

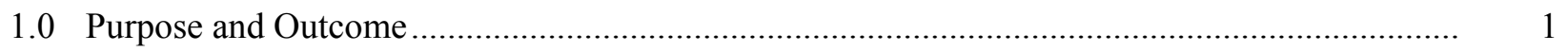

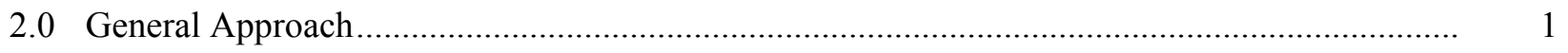

3.0 Current Installed Baseline Technology .......................................................................... 2

4.0 Efficient Multi-Load Washer Technology...........................................................................

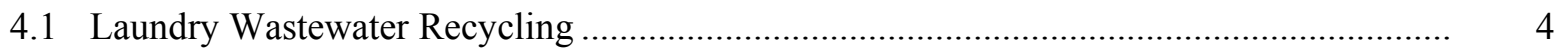

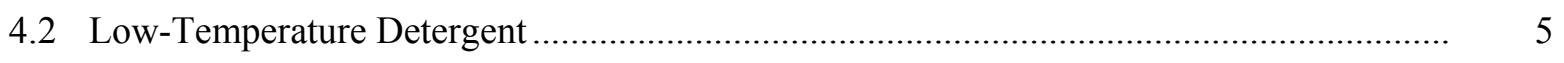

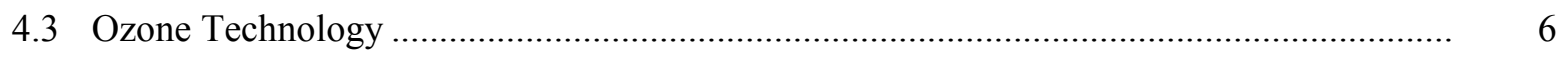

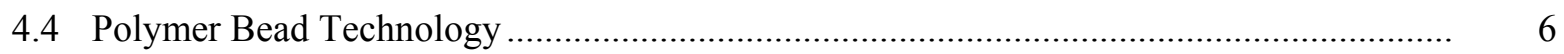

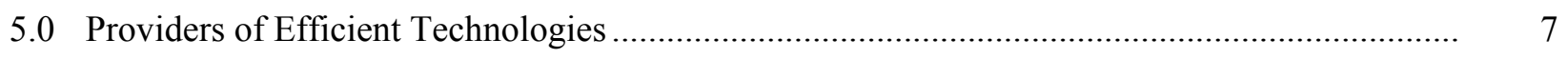

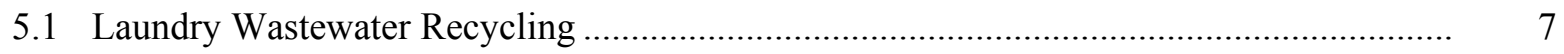

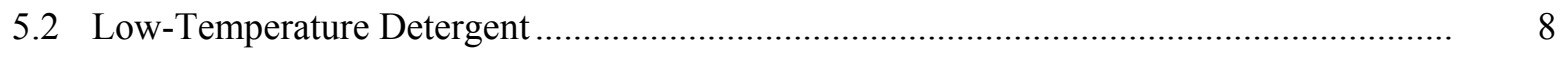

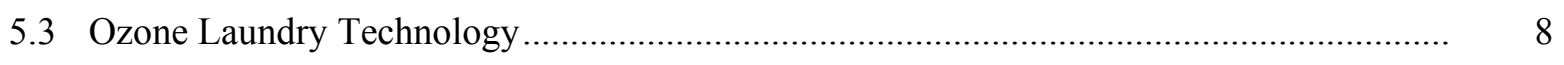

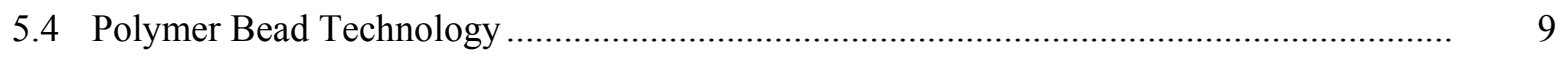

6.0 Identification of Candidate Sites for Demonstration ...........................................................

6.1 Approach to Site and Technology Selection ................................................................ 10

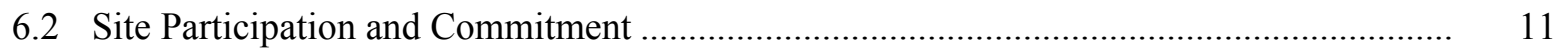

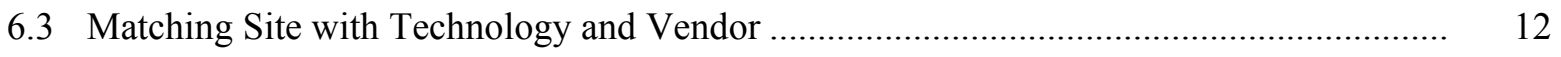

6.3.1 Vendor Participation ................................................................................. 12

6.4 Candidate Municipalities for Demonstrations............................................................ 13

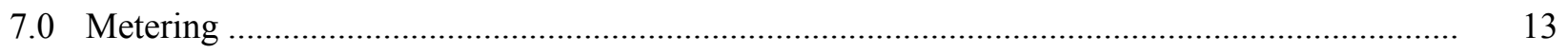

7.1 Candidate Site Retrofit System Assumptions ….......................................................... 14

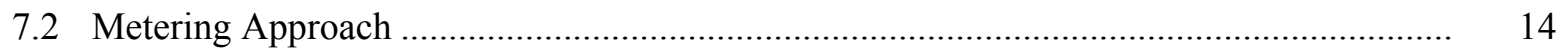

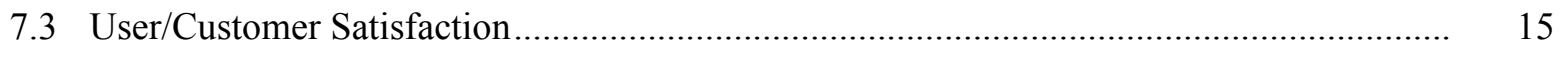

7.4 Monitoring Period, Data Intervals, and Data Collection............................................... 15

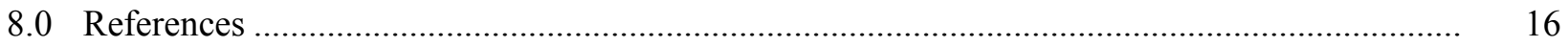

Appendix A - Examples of Retrofits Using Efficient Technology for Multi-Load Washers............. A.1

Appendix B - Data for Candidate Municipalities................................................................... B. 1 


\section{Figures}

1 Braun TSL Model 800 Washer Extractor, 900 Pound Capacity ................................................ 3

2 Exploded View of Unimac UW60PV Multi-Load Washer ........................................................ 3

3 Girbau TBS-50 Continuous-Batch Washer............................................................................ 4

$4 \quad$ Wastewater Recycling Process (Riesenberger 2006).......................................................... 5

5 Ozone Generator Used in Commercial Laundry Applications ............................................... 6

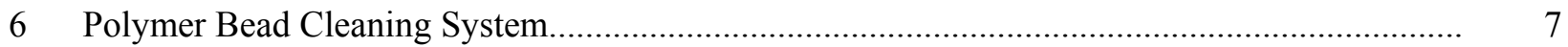

$7 \quad$ Typical Ozonation Retrofit for Multi-Load Laundry System .................................................. 12

8 Washer and Ozone Generator Metering Concept ...................................................................... 16

\section{Tables}

1 Providers of Efficient Technologies 


\subsection{Purpose and Outcome}

The purpose of this demonstration project is to quantify the energy savings and water savings of commercial laundry wastewater recycling systems and low-temperature detergent supply systems to help promote the adoption of these technologies in the commercial sector.

This project will create a set of technical specifications for efficient multi-load laundry systems (both new and retrofit) tailored for specific applications and/or sectors (e.g., hospitality, health care). The specifications will be vetted with the appropriate Better Buildings Alliance (BBA) members (e.g., Commercial Real Estate Energy Alliance, Hospital Energy Alliance), finalized, published, and disseminated to enable widespread technology transfer in the industry and specifically among BBA partners.

\subsection{General Approach}

Demonstrations will be conducted at two hotels and/or healthcare facilities, each of which will have one laundry energy savings retrofit technology installed. Candidate technologies to be demonstrated include wastewater recycling systems and low-temperature detergents (including ozone systems), which are of interest to the U.S. Department of Energy because of their energy (and water) savings and potential widespread adoption in the hospitality and health care sectors. ${ }^{1}$ In addition, water and chemicals savings and operator and customer (guest) satisfaction will be realized.

Over time, successful deployment and operation will demonstrate the long-term reliability and performance of these technologies. The market adoption of these systems will result in big wins for both end-users and manufacturers. Hotels and healthcare facilities adopting efficient laundry systems will improve their images and save energy, money, chemicals, and water. Manufacturers will develop better equipment and be directed by the strong market signal from the hotel and healthcare industries and particularly BBA members.

This demonstration project will:

- quantify the water-heating energy savings of the retrofit high-efficiency multi-load laundry systems

- quantify the total water savings of the retrofit systems

- quantify any detergent savings of the retrofit systems

- determine the life-cycle cost savings of installing the systems

- develop specifications for wide-scale deployment and market adoption of appropriate systems across the healthcare and hospitality sectors.

\footnotetext{
${ }^{1}$ The energy-savings potential is estimated to be approximately $124 \mathrm{TBtu} / \mathrm{yr}$, assuming an estimated primary annual energy consumption of $248 \mathrm{TBtu} / \mathrm{yr}$. Wastewater recycling systems or low-temperature detergents are reported to deliver $\sim 50 \%$ energy savings relative to the baseline, and the current installed base is approximately 50,000-200,000 multi-load washers; wastewater recycling systems are reported to deliver $\sim 80 \%$ water savings (NCI 2008).
} 
This project will be jointly undertaken by Pacific Northwest National Laboratory (PNNL) and Navigant Consulting, Inc. (NCI) with PNNL responsible for the overall management and coordination of the project. The project will follow a three-phase approach:

- Phase I: Select the technology platforms and the demonstration sites.

- Phase II: Determine the demonstration protocols and conduct the demonstration at the selected sites.

- Phase III: Prepare a final report that will present the results, recommendations, and conclusions. As part of Phase III, a set of technical specifications will be developed, vetted, and disseminated for wide-scale adoption by the industry and specifically for BBA members.

In addition to the overall management and coordination of the project, PNNL will be responsible for conducting one of the site demonstrations and producing a final report for one host site - targeted in the western half of the country. NCI will be responsible for conducting the other site demonstration and producing a final report for a second location - targeted in the eastern half of the country.

The project management plan, deliverable PNNL-FY13-04-01, gives a detailed description of the approach to be taken to complete each phase of the project, the deliverables in each phase, and the schedule for each deliverable. Stage gates (i.e., key decision points in the project) are also identified. In addition, the project management plan outlines the strategy for transferring this technology to the hospitality and health care industries.

\subsection{Current Installed Baseline Technology}

Commercial laundry equipment end-users span a wide range, including the following:

- Coin-operated laundries - Traditional laundromat facilities that provide coin- or card-operated laundry equipment.

- Multi-housing laundry facilities - Laundry facilities located in common areas of apartment buildings, dormitories, and other multi-family dwellings.

- On-premise laundries (OPLs) - Onsite laundry facilities in hotels, hospitals, assisted living facilities, universities, and prisons.

- Off-premise/industrial laundries - Large offsite laundry facilities that usually serve multiple customers and often replace OPLs.

- Dry cleaners - Professional cleaning establishments that use organic or other solvents to launder clothing and textiles.

This demonstration project will focus on equipment used in OPL and off-premise laundry applications. Typically, OPL and off-premise laundry facilities use multi-load washers and washer extractors, which are much larger than residential-style single-load washers. Equipment capacity can range in size from 35-900 lb of laundry per load. After cleaning, water is extracted from the laundry using high-speed spin cycles that produce forces on the order of hundreds of g's. (One "g" is defined as the acceleration due to gravity). Multi-load washers are built to be extremely durable to handle the large load sizes and the significant forces of the spin cycle. The equipment experiences high-duty cycles and must be durable enough to avoid frequent breakdowns. Figure 1 and Figure 2 show examples of typical multiload washers (Zogg et al. 2009). 

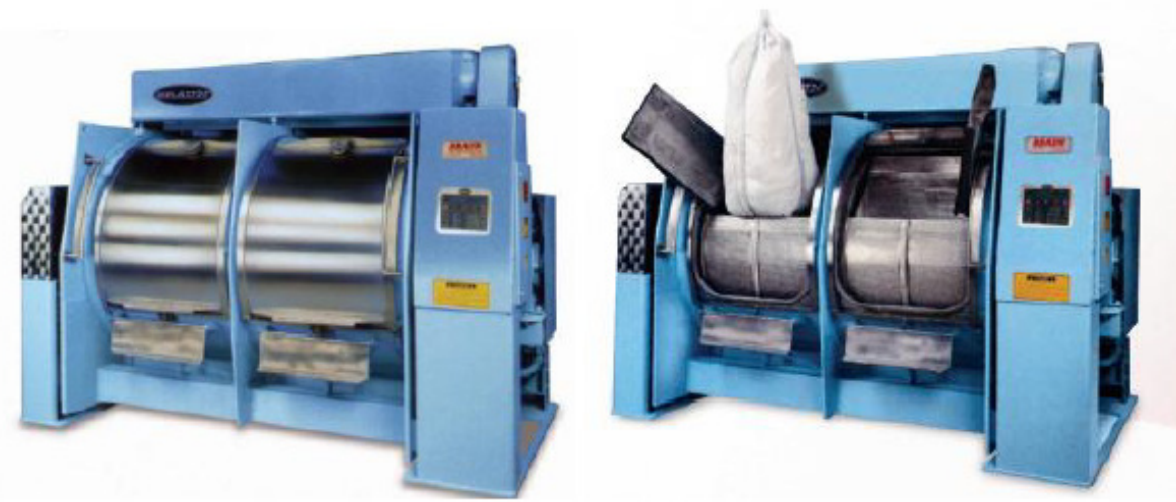

Source: Braun website (Braun 2013)

Figure 1. Braun TSL Model 800 Washer Extractor, 900 Pound Capacity
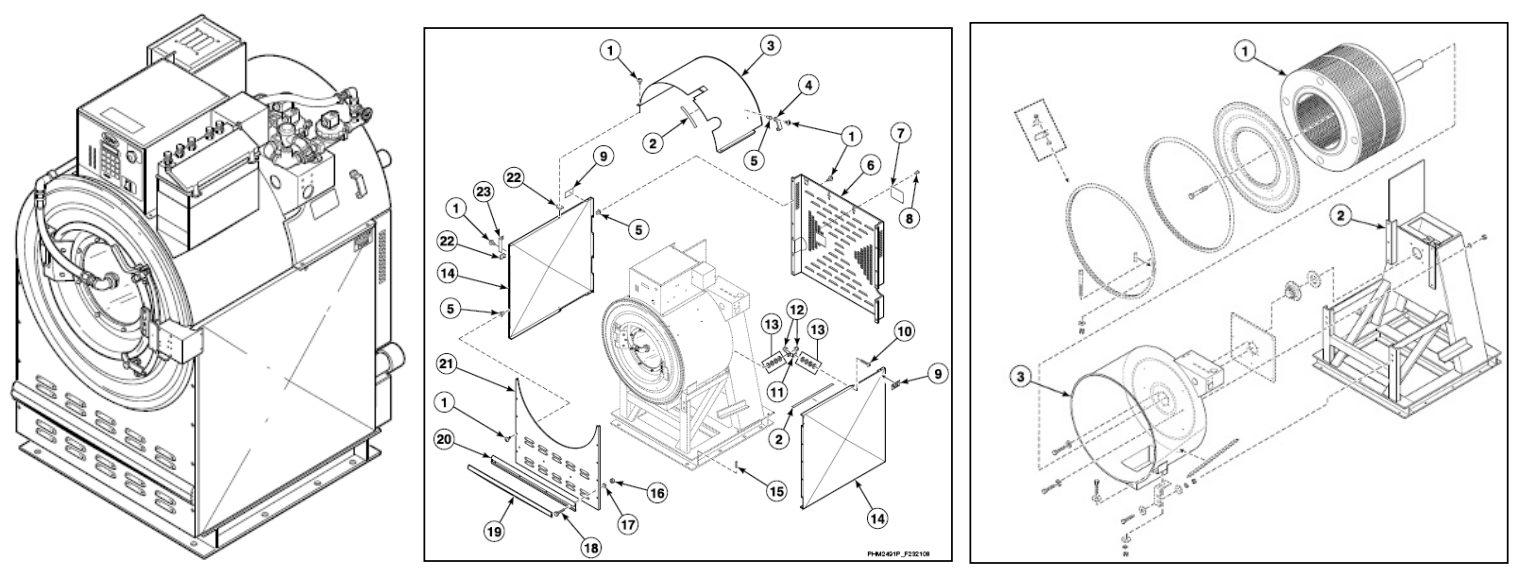

Source: Century Laundry (Century 2009)

Figure 2. Exploded View of Unimac UW60PV Multi-Load Washer

Large, centralized off-premise laundries combine the laundry operations for facilities such as hotels or hospitals. This reduces costs and helps facilities comply with local or regional regulatory requirements. In addition to using multi-load washers, many of these facilities also use tunnel washers. Tunnel washers, also called continuous-batch washers, are constructed as a series of compartments through which the clothing is continuously moved. Continuous batch refers to the continual movement of laundry through the washer, which is separated internally into batches, or compartments, that perform a specific portion of the wash process. A large internal corkscrew-shaped auger slowly turns to pull the laundry through the various compartments. Water moves in a cross-flow direction to the laundry and is therefore used several times before being discharged from the system. Most tunnel washers use a press at the end of the tunnel to compress the load to remove excess water. The compressed cakes are then transferred to the dryers. Some tunnel washers use extractors that spin the clothes to remove most of the remaining moisture before transferring the laundry to the dryers.

Tunnel washers can be as large as $8 \times 10 \times 40 \mathrm{ft}$ and contain up to 20 compartments. Modern tunnel washers feature up to 100 programmable wash programs, remote diagnostic capabilities, and automatic control of chemicals in each compartment. Wash capacities are measured in pounds/hour $(\mathrm{lb} / \mathrm{hr})$ and capacities can range from $350-6,600 \mathrm{lb} / \mathrm{hr}$ (Zogg et al. 2009). Figure 3 shows an example of a tunnel washer. 


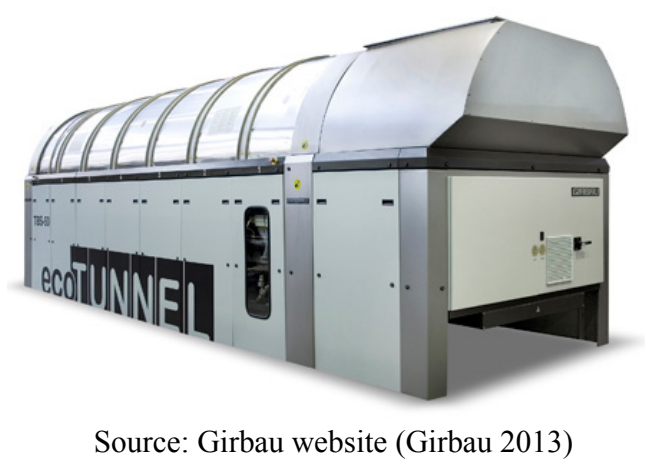

Figure 3. Girbau TBS-50 Continuous-Batch Washer

\subsection{Efficient Multi-Load Washer Technology}

Below is a description of the four efficient multi-load washer technologies to be considered for this demonstration project.

\subsection{Laundry Wastewater Recycling}

Laundry wastewater recycling is an add-on retrofit technology to improve energy and water efficiency in commercial laundries. The technology works by first cleaning, primarily removing solids, followed by disinfecting wastewater from the washers. The cleaned water is sent to a holding tank, where it is continually disinfected with oxidizing agents until it is needed for reuse, at which point it is further disinfected with ultraviolet light and sent back to the washers. A diagram of the process can be found in Figure 4.

After the initial installation and startup period, systems typically require little maintenance apart from filter replacements. Wastewater recycling has little to no impact on wash quality, and can be used in all commercial facility types, regardless of the degree of laundry soiling. Water savings are typically 80 percent, while energy savings (due to decreased water-heating load) are roughly 53 percent (Goetzler et al. 2009).

Facilities washing over 5,000 lb/day (10,000 lb/day minimum if using tunnel washers) are good candidates for a wastewater recycling retrofit. The system requires space for holding and filtration tanks and storage tanks, which vary in size and capacity depending upon the throughput requirements. Space requirements vary from $100 \mathrm{ft}^{2}$ for a small 15 gallon-per-minute (gpm) system to approximately $343 \mathrm{ft}^{2}$ for the largest system, which is capable of processing $250 \mathrm{gpm}$ (Riesenberger 2006). 


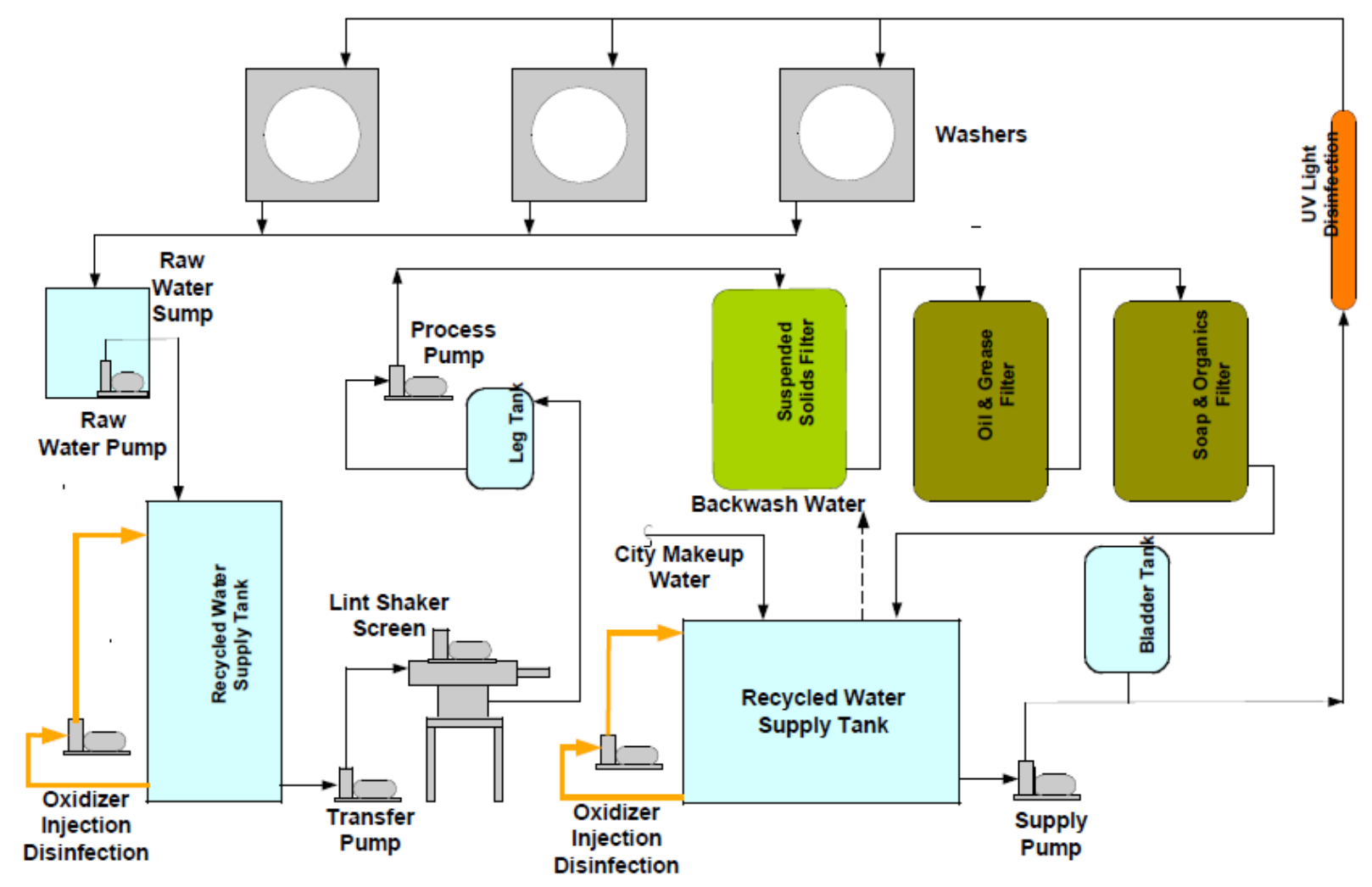

Figure 4. Wastewater Recycling Process (Riesenberger 2006)

Dozens of wastewater recycling systems have been installed nationwide. A 2007 market study from Skumatz Economic Research Associates, Inc. found that 70 percent of installations achieve energy savings greater than or equal to the expected savings and 89 percent found the water quality to be as good as or better than expected (Skumatz, 2007).

AquaRecycle, Norchem, Wastewater Resources Inc., and Kemco Systems currently offer wastewater recycling systems.

\subsection{Low-Temperature Detergent}

Low-temperature detergents are an alternative to traditional high-temperature detergents that improves energy efficiency in commercial laundries by reducing the water-heating load. The technology works by using enzymes to remove stains, which allows for operation at roughly $120^{\circ} \mathrm{F}$, rather than at the traditional $170^{\circ} \mathrm{F}$. The reduced temperature results in energy savings of approximately 47 percent. After the initial startup period, in which the appropriate chemical mix is determined for the specific application, substitution of low-temperature detergent is typically invisible to staff and requires no maintenance (Goetzler et al. 2009).

Many commercial and industrial laundry facilities may be good candidates for low-temperature detergent retrofits. However, low-temperature detergents may not be suitable for facilities that are required to use minimum wash water temperatures to ensure bacteria/pathogen destruction. Target applications are relatively small facilities such as hotels/motels, nursing homes, correctional facilities, and universities. 
Low-temperature detergents are priced comparably to traditional detergents, so significant investment in the technology is not required. Moreover, low-temperature detergent works with existing washer equipment, without any retrofitting. As a result, the technology is market ready and easy to implement. Most commercial and industrial laundry facilities are good candidates for low-temperature detergent retrofits as there are no requirements for additional equipment installation.

\subsection{Ozone Technology}

Ozone technology can also be used in low-temperature applications. Ozone, manufactured from ambient air, is injected into the water. Once in the water, it reacts with insoluble soils, making them soluble, after which the mechanical action of the washing separates the soils from the fabric. Ozone also acts as a natural disinfectant, providing sanitization in colder water temperatures. Energy is saved with this system because the water is not heated for lightly to moderately soiled laundry. The reduced water temperature results in energy savings of up to 89 percent. In addition, up to 45 percent total water savings can be achieved (NCI 2008). An example of an ozone generator used for commercial laundry facilities is found in Figure 5.

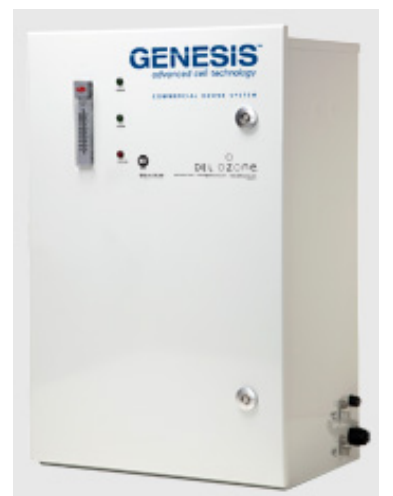

Source: DEL Ozone website (DEL Ozone 2013)

Figure 5. Ozone Generator Used in Commercial Laundry Applications

\subsection{Polymer Bead Technology}

Polymer bead cleaning is a new technology currently under development. This technology uses the absorbent properties of nylon polymer beads to clean clothes. The nylon beads are added to the wash drum with a small amount of water and detergent to loosen the dirt or stains on the clothing. The clothes are tumbled with the polymer beads for around 45 minutes. The polarity of the nylon polymer attracts stains from the clothing. Under humid conditions, the polymer becomes absorbent. Dirt is attracted to the surface and then absorbed into the center of the bead. At the end of the cycle, the polymer beads are separated from the clothing through an inner drum/outer drum rotation process.

Research conducted in the United Kingdom has shown that this technology could reduce water consumption by up to 90 percent compared to a traditional clothes washer. Including lower temperature cleaning and reduced detergent consumption, total laundry energy consumption could be reduced by up to 40 percent. Figure 6 shows a polymer bead cleaning system. 


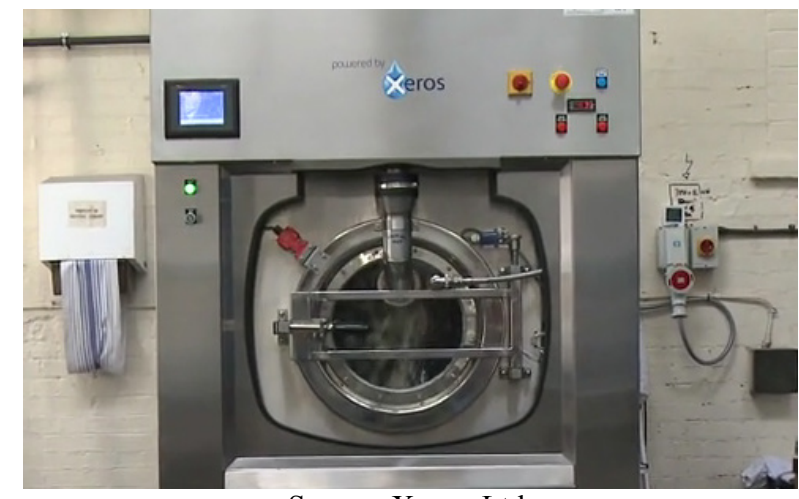

Source: Xeros, Ltd.

Figure 6. Polymer Bead Cleaning System

\subsection{Providers of Efficient Technologies}

Table 1 summarizes the identified providers of each efficient multi-load washer technology described in Section 4.

Table 1. Providers of Efficient Multi-Load Washer Technologies

\begin{tabular}{ll}
\hline \multicolumn{1}{c}{ Efficient Technology } & \multicolumn{1}{c}{ Technology Providers } \\
\hline Laundry wastewater recycling & AquaRecycle \\
& Norchem \\
& Wastewater Resources, Inc. \\
Low-temperature detergent & Kemco Systems \\
Ozone technology & EcoLab \\
& Norchem \\
& DEL Ozone \\
& ArtiClean \\
& Ozotech \\
& Aquawing Ozone Systems \\
& ClearWater Tech \\
& Ecowash \\
Envirocleanse \\
Polymer bead technology & Ozone Laundry Systems \\
\hline
\end{tabular}

Sections 5.1 through 5.4 provide additional information about each provider.

\subsection{Laundry Wastewater Recycling}

Four companies were identified that offer laundry wastewater recycling systems: AquaRecycle, Norchem, Wastewater Resources Inc., and Kemco Systems. 
AquaRecycle offers a filtration and treatment system that provides clean, disinfected, and pre-heated water for multi-load washers. The system is pre-assembled and can be installed nearly anywhere in the laundry facility. In addition, it is fully automated and system performance can be monitored remotely. AquaRecycle claims its system can reduce water and sewer costs by 80 percent and energy costs by up to 50 percent (AquaRecycle 2013).

Norchem offers a wastewater treatment and water recycling system for commercial laundry applications through its ULTRAPURE product. All Norchem systems are custom and can be manufactured to fit into tight spaces. Norchem claims up to 85 percent water savings and over 80 percent energy savings (Norchem 2013).

Wastewater Resources Inc. offers an advanced purification plant for laundry graywater called the AquaTex Ultra. AquaTex Ultra reclaims, treats, and disinfects graywater and blackwater (Wastewater Resources Inc. 2013).

Kemco Systems offers a ceramic microfiltration system that can recycle up to 90 percent of a wastewater stream. The system is compact and requires minimal maintenance. Appendix A includes the results of a case study of Kemco Systems' wastewater product (Kemco Systems 2013).

\subsection{Low-Temperature Detergent}

Two companies were identified that offer low-temperature detergent: Ecolab, Inc. and Norchem.

Ecolab Inc. is the most frequently used detergent company in commercial laundries. It offers lowtemperature detergents that work with existing washer equipment (EcoLab 2013).

Norchem also produces low-temperature detergents. Norchem claims to meet environmental regulations and reduce operating costs (Norchem 2013).

\subsection{Ozone Laundry Technology}

Ten companies were identified that provide ozone generators for commercial laundry applications: DEL Ozone, ArtiClean, Ozotech Inc., Aquawing Ozone Systems, ClearWater Tech, The Ozone Company, Envirocleanse, Ozone Laundry Systems, Ozone Water Technologies, and Total Ozone Solutions.

DEL Ozone's Genesis series is designed for commercial OPLs. The fully integrated wall-mount ozone systems are designed for installation into new or pre-existing commercial laundry operations. DEL Ozone claims that the Genesis series reduces hot water consumption by up to 85 percent (DEL Ozone 2013).

ArtiClean Ozone provides ozone generators for laundry systems through its AW and AT Series. ArtiClean Ozone claims its generators can reduce hot water consumption by up to 95 percent (ArtiClean Ozone 2013).

Ozotech Inc. produces ozone generators for various applications. Ozontech Inc. provides commercial-, industrial-, and residential-sized products for laundry, wastewater treatment, and sanitizing purposes (Ozotech Inc. 2013). Appendix A presents the results of a case study of Ozotech Inc.'s ozone generator. 
Aquawing Ozone Systems offers custom ozone technology that can be retrofit onto existing laundry systems. Aquawing Ozone Systems advertises that its Aquawing systems save energy and protect delicate linens from damage. The system is equipped with patented technology to introduce maximum amounts of ozone to ensure adequate disinfection. (Ozone Laundry Systems 2013).

ClearWater Tech boasts 200,000 ozone technology installations in six countries since 1986. It has been a leading innovator in a wide range of water and air purification. Along within installations, it has many patents pending on products it has innovated or invented (ClearWater Tech 2013).

The Ozone Company, started in 2005, has crafted its mission to save customers money and natural recourses by innovating ozone technology and developing new processes for disinfection. It has standalone and retrofit ozone systems available (The Ozone Company 2013).

Envirocleanse offers large savings on energy and hot water usage. It states a 90 percent reduction in hot water consumption, 30 percent reduction in water and sewer usage, and shorter drying times. The company's website details case studies associated with the stated savings (Envirocleanse 2013).

Ozone Laundry Systems offer technology that is designed to supply maximum amounts of ozone without sacrificing user safety. The company guarantees that the customer will be satisfied with the outcomes of the system, or the price will be refunded. The company's website includes several customer testimonials (Ozone Laundry System 2013).

Ozone Water Technologies' goal is to produce the most efficient ozone laundry system for the lowest price possible. The company is made up of professionals, project managers, and energy specialists who will tailor installations to each customer's needs to allow for maximum benefit at minimum cost (Ozone Water Technologies 2013).

Total Ozone Solutions works as a leading supplier of ozone systems. It uniquely works with utility companies to achieve the maximum incentive reimbursement for its customers. Testimonials from satisfied customers are available on the company's website. In addition, case studies on the website show the energy and water savings realized by installing a Total Ozone Solutions ozone system (Total Ozone Solutions 2013).

\subsection{Polymer Bead Technology}

This technology is currently in development by Xeros Ltd. in the United Kingdom. According to its website, Xeros Ltd. has successfully concluded two field trials in the United Kingdom. One field study is in a commercial-scale dry cleaning setting and the other is in a commercial-scale industrial setting. In addition, development is ongoing to create prototypes for residential use. The company is open to exploring research and development partnership opportunities (Xeros Ltd. 2013).

\subsection{Identification of Candidate Sites for Demonstration}

As noted in the project management plan (DOE deliverable PNNL-FY13-04-01), at least two demonstrations will be undertaken. The demonstration sites will be geographically dispersed to take 
advantage of the location of PNNL and NCI staff. Therefore, one demonstration will be in the western half of the United States and one in the eastern half of the United States.

To assist in the identification of candidate demonstration sites, key characteristics of major metropolitan areas across the country were determined that would make a multi-load laundry demonstration attractive to the hospitality and healthcare industries. Major metropolitan areas were selected due to the greater number of larger hotels and greater number of healthcare industries, providing more options for candidate demonstration sites. Data on the following characteristics were acquired and entered into a Microsoft Excel spreadsheet (see embedded file in Appendix B):

- city/state

- population

- number of hotels

- number of assisted living facilities

- numbers of hotel rooms/population

- number of assisted living facilities/population

- electric utility company/gas utility company

- water rate

- sewer rate

- commercial electricity rate

- commercial natural gas rate

- applicable utility incentives

Those metropolitan areas where there has been a significant growth in the number of hotel rooms over the past three years are identified in the spreadsheet. In addition, references for all data and a tab identifying documents of efficient laundry case studies in hospitality and health care facilities are provided.

This spreadsheet will be used to ascertain those metropolitan areas that have a combination of a large number of hotel rooms/population, assisted living facilities/population, and elevated utility rates (electric/gas/water/sewer). In addition, the servicing utilities and their incentive programs (if any) can be identified. With this information - and other key factors and attributes (see Section 6.1) - combinations of characteristics can be sorted to help prioritize those metropolitan areas (by east and west) where the team may want to focus for the best candidate demonstration sites.

\subsection{Approach to Site and Technology Selection}

The data in the spreadsheet will help the team focus on those metropolitan areas with characteristics that may make a demonstration attractive to the candidate host site due to energy and water cost savings and to the servicing utility due to incentives and/or other programs designed to help commercial customers become more efficient. These factors will increase the chances that demonstration sites can be secured. Participation by a servicing utility is important for a number of reasons:

- the servicing gas utility will be needed to provide assistance to install meters in gas lines for the metering (see Section 7.2

- either the gas or electric utility or both may have incentive or other technical assistance that could be used to help defer the cost of installation 
- the utilities can also be a conduit for technology transfer though creation and distribution of fact sheets and case studies.

However, additional key considerations are necessary for securing the demonstration sites. Primary among those considerations is reaching out to the vendors/providers of the technologies to ascertain their interest in partnering in the demonstration ${ }^{2}$ and in identifying candidate demonstration sites in those metropolitan areas selected from the spreadsheet data. The team believes that the technology providers are the best resource for identifying candidate sites given that their business model depends upon successful (and cost-effective) installations and customer satisfaction. The team will down-select from among the vendors listed above because there is not time to contact them all. The down-select will be based on discussion among the team, the service territory of the vendors, the match of technology with candidate sites (see Section 6.3), and vendor experience with the hospitality and healthcare industries.

Another key consideration is to connect with the BBA Commercial Real Estate Energy Alliance and Hospital Energy Alliance to discuss whether any of the BBA member hotels/hotel chains or healthcare facilities have experience with high-efficiency laundry and, if so, the outcome of that experience. In addition, the team can explore the potential for the BBA hospitality consortium to gauge interest by a member hotel(s) in participating in a demonstration. Lastly, BBA members can be a key conduit for transferring the technology upon completion of the demonstrations.

\subsection{Site Participation and Commitment}

Once candidate sites are selected (approximately two to five sites for each of the two demonstrations), contact will be made with the appropriate site (and possibly HQ) staff to gauge interest in a demonstration. The candidate site contact(s) may be identified through the BBA, through the candidate site headquarters staff ${ }^{3}$, through the technology provider, through the servicing utility or any combination of these resources. Initial contact will be made by phone and/or email, followed by a personal visit by PNNL or NCI staff. Once all candidate sites have been contacted and visited, the team will select the sites. An agreement will then be reached with the sites for the demonstration to proceed.

Key criteria for selection of the sites include the following:

- providing site access to PNNL, NCI, and equipment provider staff

- assisting in equipment installation and commissioning

- assisting, where necessary, in gathering data and monitoring per the proposed metering approach (e.g., detergent use)

- debugging instrumentation, if necessary

- collecting user/customer satisfaction information

- participating in documenting staff experience using the multi-load washers with the installed efficient system.

\footnotetext{
${ }^{2}$ The U.S. Department of Energy FY13 Annual Operating Plan for this work identified vendor participation and possible cost-sharing in the installation of the technology as an important element to the success of the project.

${ }^{3}$ For example, through a hotel chain, headquarters staff responsible for efficiency or sustainability initiatives across the hotel chain properties.
} 


\subsection{Matching Site with Technology and Vendor}

It is desired, but not required, that two different technologies be demonstrated in this project. However, consideration will need to be given to the characteristics of the existing laundry facility in the sites selected for the demonstrations and the preference of the candidate site staff in the final selection of the technology for the retrofit at the site.

The sites will be large, multi-bed facilities with central laundry facilities that feature multi-load washing machines. The multi-load machines should be hard-mount style with sufficient access to the hot and cold water supply lines and hot water energy source (gas or electric) for metering equipment to be installed.

In addition, sufficient room must exist to install low-temperature detergent technologies or wastewater recycling systems. Ozone equipment is not large or bulky and can have many of the components mounted on the wall behind the wash line. However, the system should be located as close as possible to the multi-load washing machines because of the nature ozone as a disinfectant (see Figure 7).

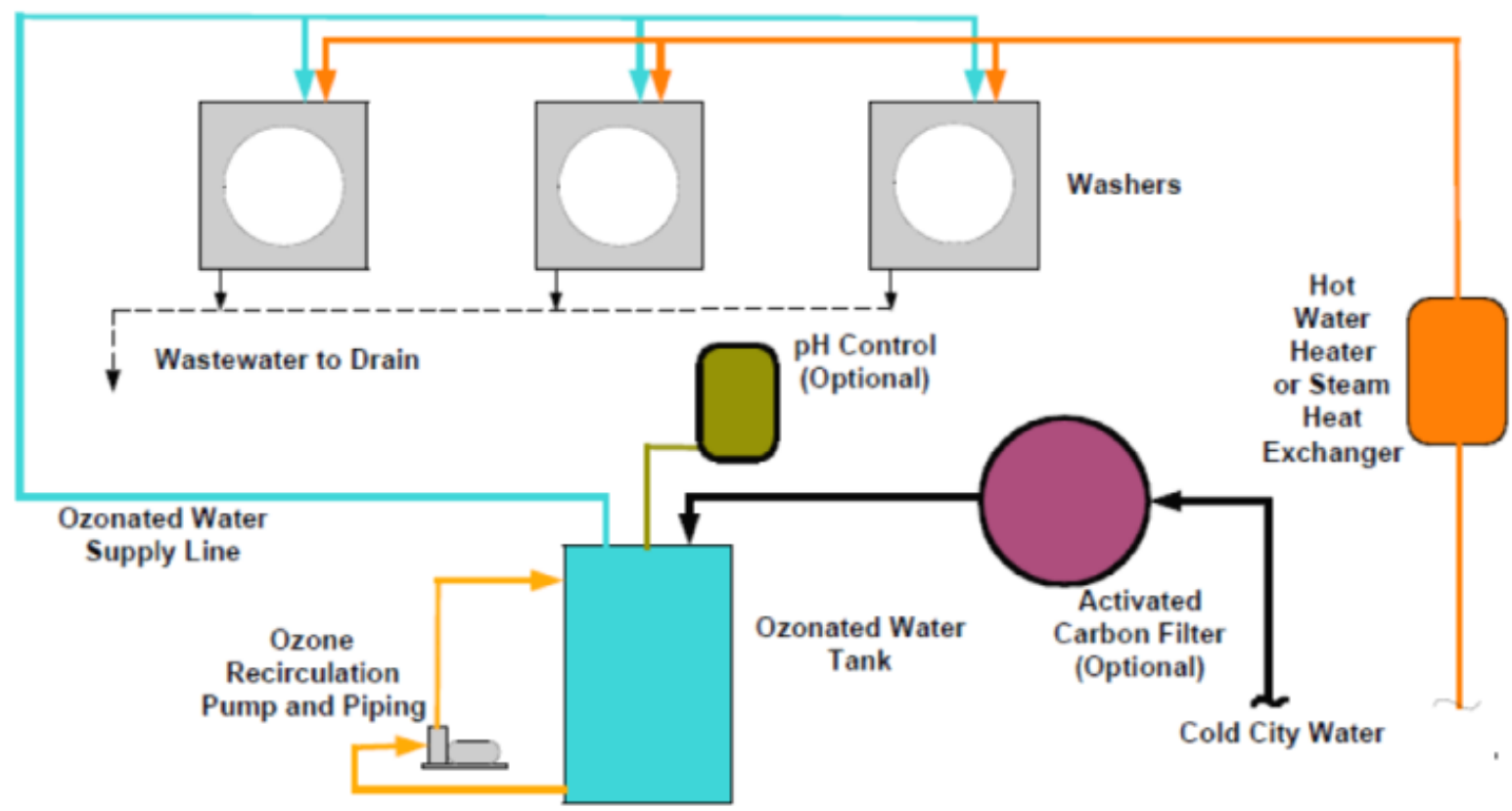

Figure 7. Typical Ozonation Retrofit for Multi-Load Laundry System

Other considerations for matching the site with the technology are the cost of the retrofit system/system metering, taking into account any vendor or utility participation.

\subsubsection{Vendor Participation}

The vendor's participation will be critical to the success of each respective demonstration and will include, but not be limited to: 
- providing the equipment $^{4}$

- providing guidance and oversight of the equipment installation

- equipment startup and commissioning

- ongoing troubleshooting support during the duration of the demonstration

- validation and verification of performance of the equipment

- removal of the equipment at the end of the demonstration. ${ }^{5}$

\subsection{Candidate Municipalities for Demonstrations}

Based on a review of the information in the spreadsheet, the following are candidate municipalities for demonstrations:

East (in no particular order)

- Washington DC

- Boston

- Chicago

- Miami

- San Juan

- Dallas

- Norfolk

- Orlando

West (in no particular order)

- Seattle

- Portland

- San Francisco

- Las Vegas

- Phoenix

- Denver

The final selection of the municipalities and candidate sites in those municipalities will follow the approach laid out above.

\subsection{Metering}

The following is a description of the generic metering approach for the selected retrofit efficient laundry system technology. A detailed metering plan that includes all metering equipment and the data collection strategy and data archiving will be prepared once the site and efficient system is determined. Photos will be taken of all equipment before, during, and after installation.

\footnotetext{
${ }^{4}$ PNNL and NCI will secure the efficient systems for the demonstrations, including exploring alternative to purchasing the efficient laundry systems outright, such as a vendor providing the equipment for the duration of the demonstration with the option for the host site to purchase the equipment at the end of the demonstration.

${ }^{5}$ The site will be given the option of keeping the equipment. The equipment will be removed if the site chooses not keep it.
} 


\subsection{Candidate Site Retrofit System Assumptions}

The following are assumptions for designing the metering approach to determine the energy and water savings and customer satisfaction with the retrofit system. These assumptions apply to any of the candidate retrofit systems.

- Both the existing laundry system and the retrofit system operate on standard commercial voltage $(120 / 208 \mathrm{~V}$ or $277 / 480 \mathrm{~V})$.

- The clothes washer equipment is multi-load, hard-mount style.

- There is access to, and sufficient room around, the hot/cold water supply lines to the washers for installing flow metering equipment.

- There is access to, and sufficient room around, the water heater(s) energy source (gas or electric) for installing flow metering equipment.

\subsection{Metering Approach}

The following is the metering and data collection approach that will ensure a credible evaluation of the retrofit system. This approach will include monitoring of all relevant system inputs including:

- Clothes washer hot and cold water use using real-time, in-line meters for:

- cold water volume flow and temperature

- hot water volume flow and temperature

- recycled water volume flow and temperature.

- Equipment energy use using real-time meters for:

- electrical energy use for ozone generator

- electric energy use for water recycling system (pumps/motors and other ancillary loads including controls)

- natural-gas $^{6}$ (or electricity) use for water heating

- electrical energy use of washer(s) (capturing motor/pump/electronics energy use)

- electrical/gas energy use of dryer(s).

- Equipment total usage characteristics:

- Washer cycles (turns) for the monitoring period (tracked daily, weekly, or monthly).

- Washer formula selection. Some washers have $\sim 100$ different wash formulas controlled by a computer touchscreen for specific types of loads (e.g., sheets, towels, dark, cotton, white). Each formula will alter the washing characteristics (e.g., detergent, water temperatures, and time) and it is important to record these formulas for the pre- and post-periods of monitoring.

\footnotetext{
${ }^{6}$ Note that metering of a natural gas line may need to involve the cooperation of the gas utility given the complexity of installing gas metering equipment in the laundry facility, which may require temporarily shutting down the gas line.
} 
- Weight of laundry for the monitoring period. Many of the new multi-load machines automatically display the weight of each load and it is important to record this data for the pre- and post-periods of monitoring.

- Other/non-metered. The following will be manually recorded:

- detergent use

- fabric softener use

- other chemical use.

\subsection{User/Customer Satisfaction}

User and customer satisfaction is important to successfully transforming the industry to adopt and retrofit multi-load laundry systems with efficient technology. User (e.g., laundry system operators, facility managers, owners, and customer (guests)) feedback will be sought for both pre- (baseline) and postsystem installation. This includes, but is not limited to the following:

- Discussions with the laundry operations and maintenance staff and with the facility owner/operator regarding:

- Throughput - has the historical throughput of the laundry (pounds per hour or per day) changed pre- and post-system installation and if so, why?

- Ease of operation - has the operating characteristics of the laundry system changed pre- and postsystem installation and if so, what are those changes?

- Interface with existing equipment - has the complexity/ease of operation of the equipment (including any added equipment) changed pre- and post-system installation and if so, what are those changes and how have they impacted the overall laundry operations?

- Human resources - has there been a change in labor or maintenance requirements and staffing pre- and post-system installation and if so, what are those changes?

- Customer satisfaction will be determined through discussions with the facility's interface (e.g., owner/operator) with the customers (e.g., hotel guests) regarding cleanliness, smell, softness, other (to be determined).

\subsection{Monitoring Period, Data Intervals, and Data Collection}

The period of data collection should be in the range of 3 to 5 months for both the pre- and postsystem retrofit periods. Final durations will be determined by understanding any expected use variance over the study period.

All non-real-time metered data will be collected at intervals in consultation with the laundry operators and facility owner. Any data that can be collected from electronic and/or archived data (e.g., washer formula selection) will be collected at intervals coordinated with the laundry operators and take into account the data storage media characteristics. 
All real-time metered measurements will be time-series in nature at 5-minute intervals. Water metering intervals will be revisited after specific meters are selected and be based on technology type. Data collection will be specified as remote enabled - pending data transfer communications availability.

Figure 8 presents a typical metering configuration and equipment for ozone and water-reuse systems, respectively. A typical metering configuration for the system in Figure 4 would be similar to Figure 8 in that all water flow and water temperatures and the electrical use for all pumps, motors, and injection systems would be metered. All data would be collected by a central onsite data logger with remote data download capability.

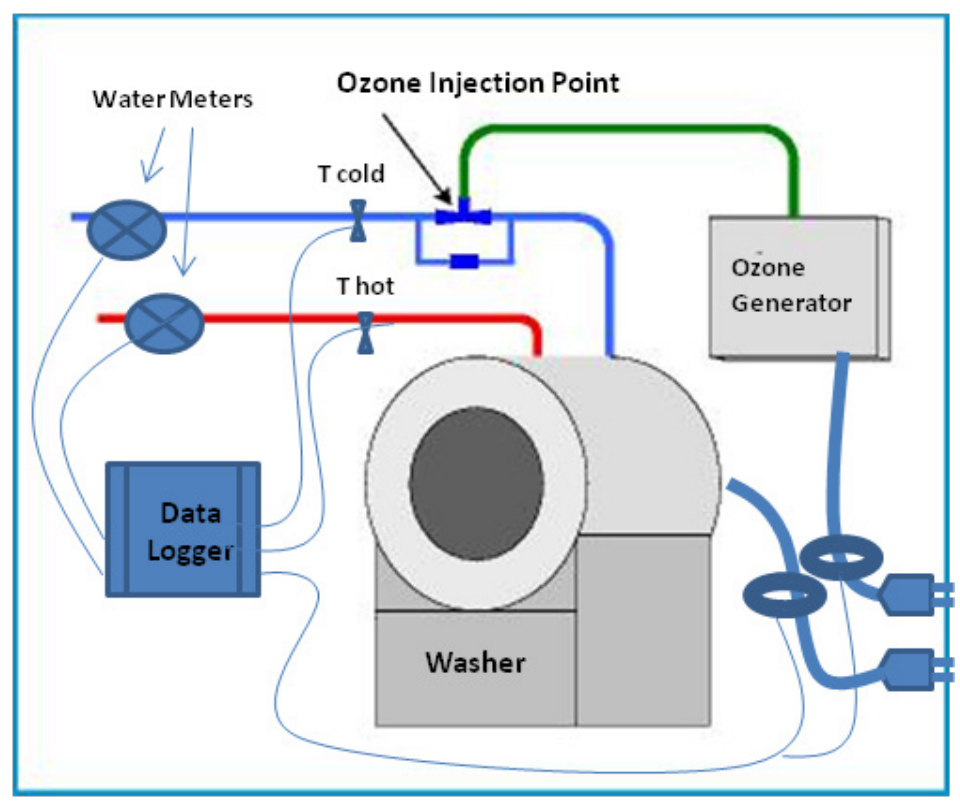

Figure 8. Washer and Ozone Generator Metering Concept

\subsection{References}

ArtiClean Ozone 2013. “ArtiClean Ozone Laundry Systems.” ArtiClean Ozone. Web. 21 Feb. 2013. $<$ http://www.articlean.com/>.

AquaRecycle 2013. "Recycle System Features.” AquaRecycle. Web. 21 Feb. 2013. $<$ http://www.aquarecycle.com/laundry-wastewater-system-features.php $>$.

Braun 2013. "Washer Extractors." Braun. Web. 20 Feb. 2013. <http://products.gabraun.com/\#productcategories/washers>.

Century 2009. "Manuals." Century Laundry- Coin Laundry equipment, parts and stores for sale serving the coin laundry business. Web. 07 Sept. 2009. <http://www.centurylaundry.net/manuals_MENU.htm>.

Clearwater Tech, 2013. “About Us” ClearWater Tech. Web. 28, Feb. 2013.

$<$ http://www.cwtozone.com/index.php?page=company $>$. 
DEL Ozone 2013. "Commercial Ozone Sanitation Products.” DEL Ozone. Web. 21 Feb. 2013. $<$ http://www.delozone.com/products/commercial-products.php>.

Ecolab 2013. "Laundry.” Ecolab. Wed. 21 Feb. 2013. <http://www.ecolab.com/solutions/laundry>.

EnviroCleanse 2013. “How It Works”. EnviroCleanse. Web. 28 Feb. 2013.

$<$ http://envirocleanse.com/How\%20It\%20Works.htm>.

Girbau 2013. "Batch Tunnel Washers." Girbau. Web. 20 Feb. 2013. <http://www.girbau.com/laundryproduct/multitunnel/TBS-\%20Multi>.

Goetzler et al., "Situational Analysis - Laundry Wastewater Recycling” (Navigant Consulting, Inc., 2009).

Goetzler et al., "Situational Analysis - Low Temperature Detergent” (Navigant Consulting, Inc. 2009).

Kemco Systems 2013. “(CMF) Ceramic Microfiltration System.” Kemco Systems. Web. 21 Feb. 2013. $<$ http://www.kemcosystems.com/Water-System-Components/Ceramic-Microfiltration.html $>$.

NCI 2008. "Commercial Laundry Technology Market Review." Presentation for Southern California Gas. Navigant Consulting, Inc. 28 July 2008.

Norchem 2013. "Norchem at a Glance.” Norchem. Web. 21 Feb. 2013. <http://norchemcorp.com/>.

The Ozone Company, 2013. “About the Ozone Company”. The Ozone Company. Web. 28, Feb. 2013. $<$ http://www.theozonecompany.com/about-the-ozone-company.htm>.

Ozotech Inc. 2013. "Clean Water for the World.” Ozotech Inc. Web. 21 Feb. 2013.

$<$ http://www.ozotech.com/>.

Ozone Laundry Systems. 2013. “Aquawing Ozone System” Ozone Laundry, Web 28 Feb. 2013.

$<$ http://www.aquawingozone.com/>

The Ozone Laundry System. 2013. “About Us” Ozone Laundry, Web. 28 Feb. 2013.

$<$ http://www.ozonelaundrysystems.com/About.html $>$.

Ozone Water Technologies, 2013 “Experienced Specialists - Ozone Water Technologies "” Ozone Water Technologies, Web. 28 Feb. 2013. < http://www.ozonewatertech.com/about-us/>.

Riesenberger, James. "PBMP - Commercial Laundry Facilities” (Koeller and Company, 2006).

Skumatz, Lisa A. and Freeman, David. Skumatz Economic Research Associates, Inc. (SERA), “OnPremise Laundry Waste Water Recycling Study,” August 2007, p. 20-21.

Total ozone Solutions. 2013. “Why Use Total Ozone Solutions?”. Total Ozone Solutions. Web. 28 Feb. 2013. < http://www.totalozonesolutions.com/about/>.

Wastewater Resources Inc. 2013. "Industrial Products: AquaTex Ultra.” Wastewater Resources Inc. Web. 21 Feb. 2013. <http://www.h2oreuse.com/Ultra.html>. 
Xeros Ltd 2013. "Polymer Bead Technology.” Xeros. Web. 21 Feb. 2013.

$<$ http://www.xerosltd.com/xeros-marketing.htm>.

Zogg et al., "Energy Savings Potential and RD\&D Opportunities for Commercial Building Appliances" (Navigant Consulting, Inc., 2009). 


\section{Appendix A}

\section{Examples of Retrofits Using Efficient Technology for Multi-Load Washers}





\section{Appendix A}

\section{Examples of Retrofits Using Efficient Technology for Multi-Load Washers}

\begin{tabular}{|c|c|c|}
\hline Location and Technology & Description & Results \\
\hline $\begin{array}{l}\text { North Carolina Hospital } \\
\text { Wastewater Recycling }\end{array}$ & $\begin{array}{l}\text { A hospital located in North Carolina } \\
\text { installed a Kemco wastewater } \\
\text { recycling system because of } \\
\text { restriction in water availability and } \\
\text { increasing water costs. }\end{array}$ & $\begin{array}{l}\text { - Laundry wastewater is pumped from the } \\
\text { facility to the recycling system. The water is } \\
\text { then pumped back to the laundry's hot water } \\
\text { system where it is sent to the continuous- } \\
\text { batch washers. } \\
\text { - The recycling system provides up to } \\
90 \text { percent of the laundry water needs. }\end{array}$ \\
\hline
\end{tabular}

Crowne Plaza, Pentagon City

\section{Ozone Technology}

The Comfort Inn \& Suites, Boston

Ozone Technology
The laundry facility at the Crowne Plaza is comprised of three large commercial-grade clothes washers and three gas-fired clothes dryers. The washers are served by two 100 gallon condensing gas water heaters that are dedicated to this use. In March of 2011, the Crowne Plaza installed a laundry ozone generator and connected it to the three clothes washers.
- Early indications are this system is working very well. Laundry staff report detergent use is down by one-third, towels and sheets are cleaner, and hot water use is greatly reduced.

- The preliminary economic analysis showed an average natural-gas savings of 10.2 therms per day to be balanced against an average increase in electricity use of $6.5 \mathrm{kWh}$ per day.

- Valued at recent costs of $\$ 1.10$ per therm and $\$ 0.10$ per $\mathrm{kWh}$, the net economic benefit of this system is roughly $\$ 10.50$ per day or $\$ 3,800$ per year.
The Comfort Inn \& Suites Boston/Airport is located near Boston Logan International Airport and is managed by the Saunders Hotel Group (SHG). Ozone laundry equipment was installed at hotel.
- SGH has installed an ozone laundry system by Ozotech Inc. to conserve both energy and water. The machine is operated with cold water and the ozone acts as a disinfectant. As a result, SHG saves heat energy (by using cold water). The hotel washes guest room linens and towels with this system.

- The ozone laundry system has capital costs of $\$ 36,000$ with a payback of two years. The utility costs savings include a 25 percent reduction in water consumption, chemicals, sewage output, and electricity. There is an 86 percent reduction in hot water usage. 


\author{
Wyndham Hotels and \\ Resorts, San Jose
}

Total Ozone Solutions

Report on the Monitoring and Assessment of Water

Savings From the Coin-

Operated Multi-Load

Clothes Washers

Voucher Initiative

Program

\section{San Diego County Water Authority}

Nursing Center

Rome, GA

\section{The Ozone Company}

Ozonated Laundry Systems in Hospitality Facilities

\section{PG\&E}

Nursing Center

Newton, Massachusetts

The Ozone Company

Hampton Inn

Brookfield, Wisconsin

Aquawing Ozone
The Wyndham Hotels and Resorts chose a San Jose hotel to install the Total Ozone Solutions technology onto the existing laundry system.

This whitepaper attempts to explore the notion that top-load washers use more water and energy than similar front-load washers.

A state of the art ozone system was retrofit onto an existing washer machine within a nursing center in Rome, Georgia.

This document details existing ozone technologies and the total savings offered by installing or retrofitting these systems into largescale hotel laundry facilities.

A state of the art ozone system was retrofit onto an existing washer machine within a nursing center in Newton, Massachusetts.

Detailed case study that illustrates the benefit of installing an ozone system onto washers. Project was completed in November 2010.
- Estimated annual savings of hot water Metered - 1,281,875 gallons.

- Therm Savings from Washer Hot Water Reduction - Metered - 857,867.

- Therm Savings from Dryer Usage Reduction - Unmetered - 2,773.

- Over the 10 year life-cycle of a front load washer, it was determined that a total of $\$ 104$ would be saved by using the washer three times a day. This increased to $\$ 143$ and $\$ 179$ if the washer was used 4 or 5 times per day, respectively.

- The total annual savings due to the retro fit was $\$ 15,184$.

- The annual cost of operation for a single washer before the technology install was $\$ 650 / y r$. After the install, it dropped to $\$ 140 / \mathrm{yr}$.

- 11 differing case studies are given that detail location, savings, project cost, and incentives paid by PG\&E.

- PG\&E details both the environmental and economic benefits of installing an ozone system.

- The total annual savings due to the retro fit was $\$ 23,929$.

- The annual cost of operation for a single washer before the technology install was $\$ 1.92 / y r$. After the install, it dropped to $\$ 333 / \mathrm{yr}$.

- Total Project cost : $\$ 11,540$

- Annual Savings: 874 kWh, 112,840 gallons of water, and 3,103 Therms. 
Appendix B

\section{Data for Candidate Municipalities}





\section{Appendix B}

\section{Data for Candidate Municipalities}

Attached is an Excel spreadsheet of data for candidate municipalities. The metropolitan areas in the spreadsheet are among the top 50 hotel markets in the United States (and Puerto Rico) (see www.lodgingconference.com Smith Travel Research 2012).

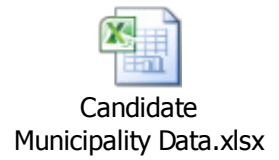






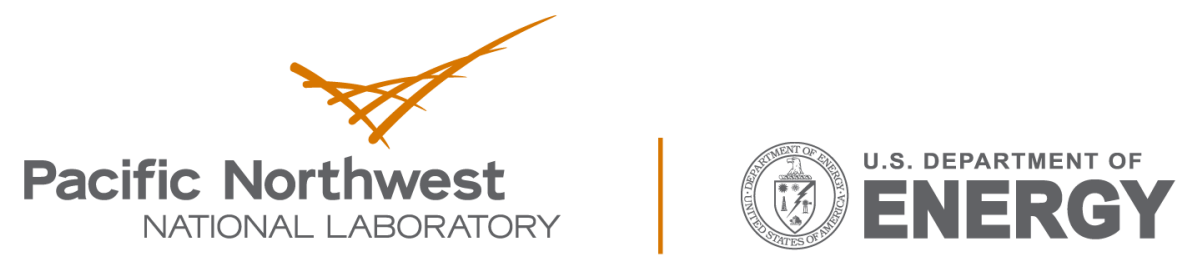

Proudly Operated by Battelle Since 1965

902 Battelle Boulevard

P.O. Box 999

Richland, WA 99352

1-888-375-PNNL (7665)

www.pnnl.gov 